\title{
EFFECT OF USING DIFFERENT LEVELS OF DRY OR GERMINATED FENUGREEK SEEDS ON PRODUCTIVE AND REPRODUCTIVE PERFORMANCE OF DAIRY ZARAIBI GOATS
}

\author{
Ebtehag I. M. Abou-Elenin; M. M. El-Badawy; Heba A. El-Sanafawy and Y. H. Hafez \\ Animal Production Research Institute (APRI), Agricultural Research Center, Dokki, Giza, Egypt.
}

(Received 25/5/2016, Accepted 5/7/2016)

\section{SUMMARY}

$\mathrm{T}$ his study aimed to evaluate the effect of supplemented diets of lactating goats by three levels $(0,10$ and $30 \mathrm{gm} /$ goat/day) from either dry (ungerminated; DFS) or germinated fenugreek seeds (GFS) on their productive and reproductive performance. A feeding trial was conducted using forty-five Zaraibi goats (31.2 $\pm 0.32 \mathrm{~kg} \mathrm{LBW}$ and aged 3-4 years) at late pregnancy (two months before parturition) and postpartum periods which lasted 210 days (after parturition). The trial was continued during winter and summer seasons. Animals were divided into five similar groups (9 animals each) using the randomized complete block design. They were fed as groups on a basal ration where concentrate feed mixture (CFM) was $50 \%$ of requirements according to NRC (1981); while, roughage was offered at ad-libitum (berseem in winter and corn silage (CS) in summer). Control group (G1) fed ration without supplement while, G2 and G4 fed supplemented rations with 10 and 30g dry fenugreek seed/head/day; respectively. In addition, G3 and G5 fed supplemented rations with 10 and $30 \mathrm{~g}$ germinated fenugreek seed/head/day; respectively. At the same time, five digestibility trials were conducted twice during experimental period in winter and another in summer season to determine the digestibility and feeding value of the experimental rations. Results indicated that germinated seeds process increased most of amino acids content in fenugreek seeds especially aspartic acid, phenylalanine and leucine. During winter and summer, feed intake and digestibility for all nutrients were significantly $(\mathrm{P}<0.05)$ increased by using germinated seeds with $30 \mathrm{~g}(\mathrm{G} 5)$ than those of the other groups. The same trend was observed with feeding values (TDN, DCP and DE). Daily milk yield was significantly increased with using level $30 \mathrm{~g}$ seeds as feed additive over the whole experimental period. Also, an improvement in $4 \%$ fat corrected milk yield was observed being 129, 120, 111 and $108 \%$ for G5, G4, G3 and G2 based on G1 as control (zero additives) over the 210-d experimental period. Milk fat and total solid contents were significantly higher for G5 than those of the others. While, no significant differences were observed for values of lactose and solid non-fat. There was an improvement in feed efficiency as kg produced milk per kg DMI, TDNI or DCPI for G5 (30 g germinated additive) in comparison of control and the other tested rations. So, it was reflected on economical efficiency which recorded $112 \%$ increase for G5 comparing with control $100 \%$ during experimental period. No deleterious effects on liver, kidney functions and general health of the animals those were fed the manipulated rations. Germination process with level $30 \mathrm{~g}$ additive fenugreek seeds had significant $(\mathrm{P}<0.05)$ positive effect on final weight, total gain and average daily gain for kids during suckling period. Also, it noticed that mortality rate gradually decreased with increasing additive levels or GFS versus DFS. There were essential improvement in reproductive performance of does in next mating season as estrus rate (\%), fertility rate and prolificacy traits. It was concluded that using germinated fenugreek seed as feed additive with $30 \mathrm{gm} / \mathrm{head} /$ day was more effective in lactating goats where it can pronounced enhance feed intake, digestibility, feeding values, milk production, feed efficiency, some blood parameters, economic efficiency, kids performance, decrease kids mortality rate and improve reproductive performance for goats in next mating season.

Keywords: Fenugreek, germinated seeds, digestibility, milk production, blood parameters, economic efficiency, kids mortality, reproductive performance and goats.

\section{INTRODUCTION}

One of the most successful attempts accomplished in the last decade is using a lot of feed additives such as seeds, leaves and other parts of medicinal plants as well as the biological and chemical additives. These additives potentially have many activated compounds which largely enhancing help in improving animal productivity and increasing economical efficiency. 


\section{Abou-Elenin et al.}

Medicinal plants such as Fenugreek seeds, Carumcarvi, Nigella sativa and Chamomile flower considered as useful natural resources for treating diseases and improving animal productivity (Kholif and Abd El-Gawad, 2001). Medicinal plant seeds improved the productivity of lactating animals, increasing prolactin and growth hormone release, in addition to activating udder tissues and furthermore increasing glucose concentration with reducing cholesterol concentration in blood (Abo El-Nor et al., 2007). Fenugreek (Trigonella foenum graecum L.) is an annual herb of the leguminous family indigenous to Western Asia and Southeastern Europe. It has long been cultivated in the Mediterranean area, India and North Africa.

Germination as a process can generally improve the nutritive value of seeds (Chen, 1970). Chen et al. (1975) reported that germination of seeds did not require sunlight or soil; also, the time of sprouting was short with highly yield and quality. There is lake in information about using and effect of germinated fenugreek seeds supplementation to the diets of ruminants on their productive performance.

The aim of this work is to study the effect of using different levels of fenugreek seeds as feed additives either dry or germinated on milk yield and composition, feed efficiency, some blood parameters and economical evaluation of lactating goats as well as suckled kids performance and mortality and reproductive performance for goats in next mating season.

\section{MATERIALS AND METHODS}

\section{Animals and feeding trials:}

Forty-five Zaraibi goats at the last two months of gestation were divided into five similar groups (nine animals each) using randomized complete block design at Sakha Experimental Station at Kafr El-Sheikh province belonging to Animal Production Research Institute (APRI). Goats averaged $31.2 \pm 0.32 \mathrm{~kg}$ live body weight and aged 3-4 years. The experimental treatments lasted 270 days (60 days before kidding date and continued by 210 days of lactation period; 120 days in winter and 90 days in summer). Feeding requirements were adjusted biweekly according to weight changes and milk production. They were fed by grouping regime on a basal ration where concentrate feed mixture (CFM) was $50 \%$ of requirements according to NRC (1981); while roughages were given at ad-libitum (berseem in winter, corn silage (CS) in summer). Animals were randomly assigned to receive one of experimental treatments as following:

Group1 (control) received basal ration without additives while groups G2 and G4 fed basal ration plus 10 and 30g dry fenugreek seed (DFS)/head/day, respectively and G3 and G5 fed basal ration plus 10 and $30 \mathrm{~g}$ germinated fenugreek seed (GFS)/head/day on DM basis; respectively as feed additives. Water was available all day. The CFM consisted of $40 \%$ wheat bran, $30 \%$ yellow corn, $24 \%$ undecorticated cotton seed meal, $3 \%$ molasses, $2 \%$ limestone and $1 \%$ sodium chloride. Chemical composition of CFM, berseem, corn silage and dry or germinated fenugreek seeds are presented in Table (1).

Table (1): Chemical composition of feed ingredients (\% on DM basis).

\begin{tabular}{lccccccc}
\hline Item & DM & OM & CP & CF & EE & Ash & NFE \\
\hline Concentrate Feed Mixture (CFM) & 92.19 & 92.83 & 14.53 & 10.72 & 3.11 & 7.17 & 64.47 \\
Berseem (In winter) & 15.11 & 89.55 & 12.90 & 28.78 & 1.79 & 10.45 & 46.08 \\
Corn silage, CS (In summer) & 26.10 & 92.46 & 9.16 & 28.32 & 1.81 & 7.54 & 53.17 \\
Dry fenugreek seed (DFS) & 92.10 & 96.49 & 22.32 & 7.78 & 8.11 & 3.51 & 58.28 \\
Germinated fenugreek seed (GFS) & 85.79 & 96.63 & 23.11 & 10.12 & 8.95 & 3.37 & 54.45 \\
& & & & & & & \\
\hline
\end{tabular}

\section{Preparation of germinated seeds:}

Fenugreek seeds were soaked in water at room temperature (2-3 volumes of water:1 volume of seeds) for $14 \mathrm{~h}$. The seeds were rinsed with water and then sprayed with $0.02 \%$ sodium hypochlorite solution at 4-hourly intervals to inhibit microbial growth (Silva and Luh, 1979). Seeds were spread on wet thin layer of rice straw in stainless steel baskets. The temperature ranged from 25 to $28^{\circ} \mathrm{C}$ during the 5 days of germinating period. Samples were taken before (DFS) and after germination (GFS) to analyze chemical composition and amino acids content. 


\section{Digestibility trials:}

Ten in vivo digestibility trials were conducted during experimental period (five in winter and another five in summer) simultaneously on the animals of feeding trial, to determine the digestibility and feeding values of the experimental rations using acid insoluble ash (AIA) method which described by Van Keulen and Young (1977). Representative samples of feed and feces were kept for proximate analysis according to AOAC (1995). Blood samples were taken from Jugular vein of three lactating goats one month before kidding and four months after kidding and at the end of the experimental period seven months after kidding of each group before morning feeding. Samples were centrifuged at $3000 \mathrm{rpm}$ for 20 min to obtain blood serum. The supernatant was frozen and stored at $-20^{\circ} \mathrm{C}$ for subsequent analysis. Total protein and albumin were determined according to Armstrong and Carr (1964) and Doumas et al. (1971); respectively, while globulins were determined by differences. Creatinine and urea were determined as kidney functions according to Schirmeister (1964) and Fawcett and Scott (1960), respectively as well as, aspartate (AST) and alanine (ALT) aminotransaminases activities were determined as liver function according to Young (1990).

\section{Sampling and analysis of milk:}

Animals were handily milked twice daily and milk yield was recorded. Individually, milk samples were collected every two weeks along the experimental period (210 days). Milk samples were analyzed for fat, protein, lactose and total solids by infrared spectrophotometry (Foss 120 Milko-Scan, Foss Electric, Hillerød, Denmark) according to AOAC (1997) procedures. Solids-not-fat (SNF) was calculated. Fat corrected milk, FCM (4\% fat) was calculated by using equation of Gaines (1928):

$\mathrm{FCM}=0.4$ milk yield $(\mathrm{kg})+15$ fat yield $(\mathrm{kg})$.

Economic efficiency was expressed as the ratio between the cost of output and the input (feed consumed) based on the price (LE/ton) during experiment.

\section{Reproductive performance:}

A teaser buck was used two times daily at 6-8 am and 3-4 pm to identify does in estrus. If does appeared estrus in the morning, it were offered to fertile buck to mating, one mating at the evening (3$4 \mathrm{pm}$ ) of the same day and another mating at the morning of the next day at 6-8 am. Does showed estrus in the evening were served two times; the first at the morning $(6-8 \mathrm{am})$ of the following day and the second at the evening (3-4 pm) of the same day. Does passing two estrous cycles without heating were considered in a pregnant state. Estrus rate (ER) was calculated according to number of goats showed estrus relative to number of total does in each group. Fertility rate (FR) was calculated according to number of pregnant doe relative to number of mated does or total number of does in each group. Prolificacy rate (PR) was calculated by divided number of total kids born on number of kidded does in each group.

\section{Statistical analysis:}

Data were statistically analyzed using general linear model program of SAS (2000). Using the following model: $\quad \mathrm{Y}_{\mathrm{ij}}=\mu+\mathrm{T}_{\mathrm{i}}+\mathrm{e}_{\mathrm{ij}}$

Where: $Y_{i j}=$ observation, $\mu=$ mean, $T_{i}=$ the effect of treatment and $e_{i j}=$ =xperimental error. Duncan's multiple range test was employed to test for significant differences (Duncan, 1955).

\section{RESULTS AND DISCUSSION}

\section{Chemical composition:}

Chemical composition of experimental rations during both winter and summer seasons are shown in Table (2). All rations in winter (after kidding) were almost similar in its contents of CP, EE, NFE and ash. While, CF was slightly increased with adding fenugreek seeds (dry or germinated) with the highest 


\section{Abou-Elenin et al.}

percent were found for ration in group 5 which received GFS by $30 \mathrm{~g} / \mathrm{goat} / \mathrm{day}$. This may be due to increasing forage intake that greatly dependent in its palatability and increasing appetite for animals in supplemented rations. These results were confirmed by Degirmencioglu et al. (2016) who reported that alfalfa DM and total DM consumption increased $(\mathrm{P}<0.05)$ with adding ground fenugreek seeds (FS). The same trend was observed in summer period, where CS also is considering as a highly palatable feed for ruminants' animals.

Table (2): Chemical composition of experimental rations (\% on DM basis) during winter and summer seasons.

\begin{tabular}{|c|c|c|c|c|c|c|c|c|c|c|}
\hline \multirow{2}{*}{ Item } & \multicolumn{5}{|c|}{ In winter } & \multicolumn{5}{|c|}{ In summer } \\
\hline & G1 & $\mathrm{G} 2$ & G3 & G4 & G5 & $\mathrm{G} 1$ & $\mathrm{G} 2$ & G3 & G4 & G5 \\
\hline DM & 57.24 & 57.07 & 56.79 & 56.51 & 56.02 & 69.73 & 69.52 & 69.22 & 69.03 & 68.73 \\
\hline OM & 91.34 & 91.34 & 91.32 & 91.31 & 91.29 & 92.70 & 92.70 & 92.70 & 92.70 & 92.70 \\
\hline $\mathrm{CP}$ & 13.79 & 13.79 & 13.78 & 13.78 & 13.77 & 13.98 & 13.97 & 13.96 & 13.96 & 13.95 \\
\hline $\mathrm{CF}$ & 18.91 & 18.95 & 19.01 & 19.08 & 19.19 & 16.86 & 16.91 & 17.00 & 17.05 & 17.13 \\
\hline $\mathrm{EE}$ & 2.51 & 2.51 & 2.50 & 2.50 & 2.49 & 2.66 & 2.66 & 2.65 & 2.65 & 2.64 \\
\hline Ash & 8.66 & 8.66 & 8.68 & 8.69 & 8.71 & 7.30 & 7.30 & 7.30 & 7.30 & 7.30 \\
\hline NFE & 56.13 & 56.09 & 56.03 & 55.95 & 55.84 & 59.20 & 59.16 & 59.09 & 59.04 & 58.98 \\
\hline
\end{tabular}

In winter: after kidding until kids weaning (120days). In summer: after weaning kids until end of lactating period (90 days).

Amino acids content of dry and germinated fenugreek seeds are illustrated in Table (3). It could be observed that most of amino acids content increased after germinated process except glycine, methionine, lysine, arginine and cystine which were slightly decreased after germination processing. Aspartic acid increased from 3.18 to $6.21 \%$, threonine from 0.96 to $1.04 \%$, serine from 1.26 to $1.68 \%$, glutamic acid from 4.67 to $4.86 \%$, proline from 1.25 to $1.50 \%$, alanine from 1.21 to $1.25 \%$, valine from 1.21 to $1.36 \%$, leucine from 2.01 to $2.25 \%$, iso-leucine from 1.48 to $1.54 \%$, tyrosine from 0.97 to $1.07 \%$, phenylalanine from 1.38 to $1.71 \%$, histidine from 1.32 to $1.57 \%$ and tryptophan from 1.08 to $1.25 \%$. These increases were mainly due to the proteolytic action of enzymes which breakdown the complex protein molecules into simpler units of amino acids. This means that germinated process of fenugreek seeds was useful to increase free amino acids which have potential positive effect that enhancing animal performance.

Table (3): Amino acids content of dry and germinated fenugreek seeds (\% on DM basis).

\begin{tabular}{lcc}
\hline & DFS & GFS \\
\hline Amino acid & 3.18 & 6.21 \\
Thpartic acid & 0.96 & 1.04 \\
Serine & 1.26 & 1.68 \\
Glutamic acid & 4.67 & 4.86 \\
Proline & 1.25 & 1.50 \\
Glycine & 1.33 & 1.14 \\
Alanine & 1.21 & 1.25 \\
Valine & 1.21 & 1.36 \\
Methionine & 0.28 & 0.21 \\
Leucine & 2.01 & 2.25 \\
lso-leucine & 1.48 & 1.54 \\
Tyrosine & 0.97 & 1.07 \\
Phenylalanine & 1.38 & 1.71 \\
Lysine & 1.88 & 1.82 \\
Histidine & 1.32 & 1.57 \\
Arginine & 2.91 & 2.36 \\
Cysteine & 0.53 & 0.46 \\
Tryptophan & 1.08 & 1.25 \\
\hline FS: dryfenugreek seeds. & & GFS: germinated fenugreek seeds.
\end{tabular}


These results are confirmed by E1-Shimi et al. (1984) who found that some amino acids content decreased slightly after soaking and then increased during sprouting process. They also were proved that ascorbic acid increased from 4.23 to $8.87 \mathrm{mg} / 100 \mathrm{~g}$ after 4 days of germination and in addition they were indicated that ascorbic acid have an important role in biosynthesis of certain amino acids. On the same line, E1-Mahdy and E1-Sebaiy (1982) reported that all free amino acids increased after germination for $120 \mathrm{~h}$, while glycine decreased. On the other hand, cystine, tryptophan and proline became in free form after germination. The greatest increases in the free amino acids were observed in the amounts of serine, alanine, phenylalanine, valine, threonine and aspartic acid, while other amino acids did not change significantly $(\mathrm{p}<0.05)$ during germination.

\section{Feed intake:}

Intake of rations' ingredients on DM basis and as TDN, DCP and DE are presented in Table (4). It could be noticed that animals of group 5 had the highest values for feed intake relative to those recorded for the other groups. Results indicated that there were gradually increases in total DMI, TDNI, DCPI and DEI with increasing the supplementation levels of DFS and GFS which might be due to increases feed intake of berseem or corn silage for supplemented groups.

Table (4): Feed intake of experimental rations of lactating Zaraibi goats.

\begin{tabular}{|c|c|c|c|c|c|c|c|c|c|c|}
\hline \multirow{2}{*}{ Item } & \multicolumn{5}{|c|}{ In winter } & \multicolumn{5}{|c|}{ In summer } \\
\hline & G1 & G2 & G3 & G4 & G5 & G1 & G2 & G3 & G4 & G5 \\
\hline \multicolumn{11}{|c|}{ Feed additive (gm) on DM basis: } \\
\hline DFS (gm) & 0 & 10 & - & 30 & - & 0 & 10 & - & 30 & - \\
\hline GFS (gm) & 0 & - & 10 & - & 30 & 0 & - & 10 & - & 30 \\
\hline \multicolumn{11}{|c|}{ Feed intake as DM basis $(\mathrm{kg} / \mathrm{h} / \mathrm{d})$ : } \\
\hline$\overline{\mathrm{CFM}}$ & 0.74 & 0.74 & 0.74 & 0.74 & 0.74 & 0.74 & 0.74 & 0.74 & 0.74 & 0.74 \\
\hline Berseem & 0.612 & 0.620 & 0.629 & 0.638 & 0.654 & - & - & - & - & - \\
\hline $\mathrm{CS}$ & - & - & - & - & - & 0.38 & 0.39 & 0.39 & 0.40 & 0.41 \\
\hline $\begin{array}{l}\text { Total DM intake } \\
\text { (DMI) } \\
\text { TDN intake }{ }^{*}\end{array}$ & 1.35 & 1.36 & 1.37 & 1.38 & 1.39 & 1.12 & 1.13 & 1.13 & 1.14 & 1.15 \\
\hline (TDNI) & 0.971 & 1.002 & 1.029 & 1.050 & 1.093 & 0.808 & 0.831 & 0.852 & 0.870 & 0.900 \\
\hline DCP intake*(DCPI) & 0.154 & 0.157 & 0.160 & 0.163 & 0.169 & 0.114 & 0.116 & 0.118 & 0.120 & 0.124 \\
\hline DE intake ${ }^{*}(\mathrm{DEI})$ & 0.043 & 0.044 & 0.045 & 0.046 & 0.048 & 0.036 & 0.037 & 0.038 & 0.038 & 0.040 \\
\hline
\end{tabular}

*TDNI, DCPI and DEI in winter and summer were calculated according to feeding values in Table (5).

In winter: after lambing until kids weaning (120days). In summer: after weaning kids until end of lactating period (90 days). DFS: dry fenugreek seeds. GFS: germinated fenugreek seeds.

Results of current study are in agreement with those reported by Petit et al. (1993) and Abo El-Nor et al. (2007) who found that DM intake was increased when lactating buffaloes fed rations with different levels of fenugreek seeds. Moreover, Tomar et al. (1996) found that the fenugreek seed stimulates feed intake in dairy cattle, resulting in a significant increase in milk production. In addition to, Ismail (2000) found that DM intake gradually increased by increasing level of fenugreek seed. More recently Balgees et al. (2013a and b) found that dry matter intake was increased by approximately 49.57, 55.65 and $58.56 \%$ by increasing level of fenugreek supplement (5, 10 and 15\%), respectively. Also, Degirmencioglu et al. (2016) reported that alfalfa DM and total DM consumption increased $(\mathrm{P}<0.05)$ with adding ground fenugreek seeds (FS). Generally, the positive effect of FS on DMI was supported by many researchers (Abo El-Nor, 1999, Abo El-Nor et al., 2007 and Petit et al., 1993). The later author suggested that fenugreek seeds may be have an effective role on hypothalamus gland to stimulate hungriness center in the brain and increase the desire for eating. Also, on another interpretation, increasing of DMI, TDNI, DCPI and DEI with groups fed supplemented diet with varying levels of fenugreek seeds, may be firstly due to the saponins content in fenugreek seeds, which reflect on increasing feed intake that confirmed by results of Petit et al. (1993) who reported that isolated steroidal saponin fraction of fenugreek seeds increase feed intake and motivation to eat. Secondly, might also be attributed to the fact that fenugreek seeds increase the appetite for food (Borca et al., 2000 and Kamel, 2000). Thirdly, DFS having 0.82\% total oxalate and $0.55 \%$ oxalic acid contents, while, sprouting fenugreek reduced the contents of oxalic 
acid and total oxalates of seeds. It was diminished the two components (oxalic acid and total oxalate) during sprouted by range from 12.0 to $15 \%$ and 13.5 to $17.1 \%$, respectively, (Gad et al., 1982a). Feed intake appeared to decrease with increasing amount of oxalate in the ration (Rahman et al., 2011).

\section{Digestibility and feeding values:}

Table (5) showed data of nutrients digestibility and feeding values during winter and summer seasons. In winter, digestibility values for all nutrients (DM, OM, CP, CF, EE and NFE) were significantly higher by adding $30 \mathrm{~g}$ GFS treatment (G5) than those of other treatments except EE. While, the lowest values of all digestibility nutrients were associated with G1 (control) comparing with those of the tested rations. Non-significant difference was noticed between G3 (10 gm GFS) and G4 (30 gm DFS) for all nutrients digestibility except DM and OM digestibility. While, diet of group 3 (10 gm GFS) was significantly higher respecting DM, OM and NFE digestibility than those in diet of G2 (10 gm DFS). In consequence of digestibility trends, the feeding values as TDN, DCP and DE for diet of G5 was significantly higher than those G1, G2, G3 and G4. On the same trend diet of G4 was significantly higher TDN value than that of G3, G2 and G1 and also higher than G1 and G2 inspect of DCP and DE values. At the same time, feeding values as TDN and DE were significantly enhanced by adding $10 \mathrm{gm}$ DFS (G2) than control group, but there were insignificant effect on DCP. Generally, there were marked improvement in digestibility and feeding values associated with G5 and G3 than G4 and G2, respectively in comparison with zero-supplemented ration (control; G1). This may be extremely due to increase in amino acids content resulting in germination process.

Table (5): Digestibility and feeding values of experimental rations for lactating Zaraibi goats.

\begin{tabular}{|c|c|c|c|c|c|c|c|c|c|}
\hline \multirow{3}{*}{ Items } & \multicolumn{9}{|c|}{ In winter } \\
\hline & \multicolumn{6}{|c|}{ Digestibility (\%) } & \multicolumn{3}{|c|}{ Feeding values } \\
\hline & $\mathrm{DM}$ & $\mathrm{OM}$ & $\mathrm{CP}$ & $\mathrm{CF}$ & $\mathrm{EE}$ & NFE & TDN & $\mathrm{DCP}$ & $\mathrm{DE}^{\mathrm{A}}$ \\
\hline \multicolumn{10}{|c|}{ Experimental groups: } \\
\hline G1 & $71.98^{\mathrm{e}}$ & $76.22^{\mathrm{e}}$ & $82.91^{\mathrm{d}}$ & $61.32^{c}$ & $80.04^{\mathrm{c}}$ & $79.19^{d}$ & $71.95^{\mathrm{e}}$ & $11.38^{\mathrm{d}}$ & $3.17^{\mathrm{d}}$ \\
\hline $\mathrm{G} 2$ & $74.14^{\mathrm{d}}$ & $78.07^{\mathrm{d}}$ & $84.24^{\mathrm{cd}}$ & $64.55^{\mathrm{bc}}$ & $81.80^{\mathrm{c}}$ & $80.79^{c}$ & $73.70^{\mathrm{d}}$ & $11.56^{\mathrm{cd}}$ & $3.25^{\mathrm{c}}$ \\
\hline G3 & $75.86^{\mathrm{c}}$ & $79.47^{\mathrm{c}}$ & $84.98^{\mathrm{cb}}$ & $66.22^{\mathrm{b}}$ & $83.90^{\mathrm{bc}}$ & $82.44^{\mathrm{b}}$ & $75.17^{\mathrm{c}}$ & $11.66^{\mathrm{bc}}$ & $3.31^{b}$ \\
\hline G4 & $77.54^{\mathrm{b}}$ & $80.69^{\mathrm{b}}$ & $86.14^{\mathrm{b}}$ & $67.82^{\mathrm{b}}$ & $85.41^{\mathrm{ab}}$ & $83.36^{\mathrm{b}}$ & $76.20^{\mathrm{b}}$ & $11.81^{\mathrm{b}}$ & $3.36^{\mathrm{b}}$ \\
\hline G5 & $80.05^{\mathrm{a}}$ & $82.91^{\mathrm{a}}$ & $88.21^{\mathrm{a}}$ & $71.88^{\mathrm{a}}$ & $86.97^{\mathrm{a}}$ & $85.26^{\mathrm{a}}$ & $78.37^{\mathrm{a}}$ & $12.08^{\mathrm{a}}$ & $3.46^{\mathrm{a}}$ \\
\hline$\pm \mathrm{SE}$ & 0.382 & 0.330 & 0.521 & 1.018 & 1.249 & 0.371 & 0.324 & 0.069 & 0.015 \\
\hline \multicolumn{10}{|c|}{ In summer } \\
\hline \multicolumn{10}{|c|}{ Experimental groups: } \\
\hline G1 & $70.08^{\mathrm{e}}$ & $74.97^{\mathrm{e}}$ & $80.17^{\mathrm{d}}$ & $53.48^{\mathrm{c}}$ & $85.74^{\mathrm{c}}$ & $79.40^{\mathrm{d}}$ & $72.30^{\mathrm{e}}$ & $10.13^{\mathrm{c}}$ & $3.19^{\mathrm{e}}$ \\
\hline $\mathrm{G} 2$ & $72.26^{\mathrm{d}}$ & $76.82^{\mathrm{d}}$ & $81.61^{\mathrm{cd}}$ & $57.22^{\mathrm{bc}}$ & $86.07^{\mathrm{c}}$ & $80.89^{c}$ & $74.02^{\mathrm{d}}$ & $10.30^{\mathrm{bc}}$ & $3.26^{\mathrm{d}}$ \\
\hline G3 & $73.97^{\mathrm{c}}$ & $78.20^{c}$ & $82.37^{\mathrm{cb}}$ & $59.04^{\mathrm{b}}$ & $87.58^{\mathrm{bc}}$ & $82.47^{\mathrm{b}}$ & $75.45^{\mathrm{c}}$ & $10.38^{\mathrm{b}}$ & $3.33^{\mathrm{c}}$ \\
\hline G4 & $75.69^{b}$ & $79.41^{\mathrm{b}}$ & $83.64^{\mathrm{b}}$ & $60.86^{\mathrm{ab}}$ & $88.45^{\mathrm{ab}}$ & $83.33^{\mathrm{b}}$ & $76.51^{b}$ & $10.52^{\mathrm{b}}$ & $3.37^{\mathrm{b}}$ \\
\hline G5 & $78.17^{\mathrm{a}}$ & $81.57^{\mathrm{a}}$ & $85.92^{\mathrm{a}}$ & $65.32^{\mathrm{a}}$ & $89.73^{\mathrm{a}}$ & $85.09^{\mathrm{a}}$ & $78.70^{\mathrm{a}}$ & $10.79^{\mathrm{a}}$ & $3.47^{\mathrm{a}}$ \\
\hline$\pm \mathrm{SE}$ & 0.434 & 0.381 & 0.649 & 1.409 & 1.519 & 0.409 & 0.376 & 0.083 & 0.016 \\
\hline
\end{tabular}

In summer, the effects of DFS or GFS supplements on digestibility as well as the feeding values and their trends among dietary treatments are much longer comparable those achieved in winter period (Table $5)$, in which digestibility of DM and its all nutrients in diet G5 were significantly $(\mathrm{P}<0.05)$ higher than those found with other groups. The same trend was noted for TDN and DE. Increasing DFS level up to 30 gm in group 4 appeared to be significantly increase the digestibility of DM and OM in comparison with the corresponding values in G2. There were insignificant differences between G4 and G3 or between G3 and $\mathrm{G} 2$ in respect of $\mathrm{CP}, \mathrm{CF}$ and EE. While, diets of groups 5, 4, 3 and 2 were significantly higher in the values of DM, OM, NFE, TDN and DE than that of control group diet. In conclusion, it could be observed that nutrients digestibility were gradually increased when adding germinated seeds compared with the dry one at the same level with non-significant differences between them. Moreover, increasing level of supplement from $10 \mathrm{~g}$ to $30 \mathrm{~g}$ in experimental groups (G2 and G4) or (G3 and G5) led to significant increases in most of nutrients digestibility. No significant differ among G2, G3 and G4 in DCP values while, G5 value was significantly higher than control. These results are confirmed by Balgees et al. (2013a) who found that the digestibility of DM, CP and OM were significantly higher $(\mathrm{P}<0.05)$ for 
rations supplemented by 10 or $15 \%$ fenugreek seeds than those fed on only $5 \%$ and control diet that free from supplement. Also, current results are in agreement with those obtained by Abo El-Nor et al. (2007) who found that there was an improvement in digestibility coefficients of lactating buffaloes rations which having different levels of fenugreek seeds.

The improvement in digestibility could be justified on the basis of that fenugreek seeds contain saponins that might be have a beneficial effect on digestive efficiency. In addition, fenugreek seeds increased bacterial number in the rumen of lactating cows (Valdez et al., 1986 and Ali et al., 2005). Fenugreek also seems to play a beneficial role in digesting and absorbing of lipids by enhancing bile acid synthesis in the liver (Frankič et al., 2009). In addition, Gad et al. (1982b) demonstrated that sprouting of fenugreek markedly decreases the phytic acid and oxalate content, which adds to the high feeding value of deflavoured fenugreek (Kamer et al., 1980). It is a good source of easily digested proteins rich in amino acids (Kamer et al., 1982); it is recommended for use as a supplement for foods. Sprouting for 2 and 4 days resulted in 23.0 and $47.7 \%$ losses in phytic acid contents, respectively, with a simultaneous increase of inorganic phosphorus content (E1-Shimi et al., 1984).

\section{Milk production and its composition:}

Data of daily milk yield and its composition are presented in Table (6). It could be noticed that yield of actual milk and 4\% FCM in winter, summer and during the whole experimental period (210 days) were appeared to be significant higher with treatment that have the higher level of GFS (G5) compared to those of control and most other tested rations. However, no significant $(\mathrm{P}>0.05)$ differences either between $\mathrm{G} 2$ and G3 or also between G3 and G4 were observed. The improvement in 4\% FCM (as percent of control) during the whole lactation period (210 days) were129, 120, 111 and $108 \%$ for G5, G4, G3 and G2, respectively. The amount of milk yield during winter period was higher than that in summer period. This may be due to the peak and persistency period which found in winter period. In addition to, goats were suckling kids that stimulate more secretion of milk from udder. Moreover, berseem was offered as main forage in rations for lactating goats in winter which has greatly positive effect on milk production.

Table (6): Average daily milk yield and its composition of lactating Zaraibi goats fed experimental rations during total period (210 days).

\begin{tabular}{|c|c|c|c|c|c|c|}
\hline \multirow{2}{*}{ Item } & \multicolumn{5}{|c|}{ Experimental rations } & \multirow{2}{*}{$\pm \mathrm{SE}$} \\
\hline & G1 & $\mathrm{G} 2$ & G3 & G4 & G5 & \\
\hline \multicolumn{7}{|l|}{ Milk production kg/goat/day: } \\
\hline In winter & $0.965^{\mathrm{b}}$ & $1.030^{\mathrm{b}}$ & $1.063^{\mathrm{b}}$ & $1.116^{\mathrm{ab}}$ & $1.208^{\mathrm{a}}$ & 0.044 \\
\hline In summer & $0.625^{\mathrm{c}}$ & $0.679^{\mathrm{bc}}$ & $0.696^{\mathrm{b}}$ & $0.766^{\mathrm{ab}}$ & $0.799^{\mathrm{a}}$ & 0.039 \\
\hline Total period (210 days) & $0.795^{\mathrm{c}}$ & $0.855^{\mathrm{bc}}$ & $0.880^{\mathrm{bc}}$ & $0.941^{\mathrm{ab}}$ & $1.004^{\mathrm{a}}$ & 0.036 \\
\hline \multicolumn{7}{|l|}{$4 \%$ fat FCM: } \\
\hline$\overline{\text { In winter }}$ & $0.788^{\mathrm{c}}$ & $0.844^{\mathrm{bc}}$ & $0.882^{\mathrm{bc}}$ & $0.937^{\mathrm{b}}$ & $1.017^{\mathrm{a}}$ & 0.041 \\
\hline In summer & $0.470^{\mathrm{c}}$ & $0.512^{\mathrm{bc}}$ & $0.519^{\mathrm{b}}$ & $0.579^{\mathrm{ab}}$ & $0.604^{\mathrm{a}}$ & 0.038 \\
\hline Total period (210 days) & $0.629^{\mathrm{b}}$ & $0.678^{\mathrm{b}}$ & $0.700^{\mathrm{b}}$ & $0.758^{\mathrm{ab}}$ & $0.811^{\mathrm{a}}$ & 0.048 \\
\hline Improvement based on control $(\%)$ & 100 & 108 & 111 & 120 & 129 & \\
\hline \multicolumn{7}{|l|}{ Composition of milk (\%): } \\
\hline$\overline{\text { Fat }}$ & $3.28^{\mathrm{b}}$ & $3.30^{\mathrm{b}}$ & $3.29^{\mathrm{b}}$ & $3.39^{\mathrm{ab}}$ & $3.41^{\mathrm{a}}$ & 0.092 \\
\hline Protein & $2.68^{\mathrm{b}}$ & $2.76^{\mathrm{ab}}$ & $2.80^{\mathrm{ab}}$ & $2.84^{\mathrm{a}}$ & $2.85^{\mathrm{a}}$ & 0.050 \\
\hline Lactose & 4.26 & 4.36 & 4.36 & 4.39 & 4.24 & 0.054 \\
\hline TS & $10.76^{\mathrm{c}}$ & $10.91^{\mathrm{c}}$ & $11.04^{\mathrm{bc}}$ & $11.36^{\mathrm{ab}}$ & $11.54^{\mathrm{a}}$ & 0.129 \\
\hline SNF & 7.76 & 7.82 & 7.74 & 7.93 & 7.79 & 0.082 \\
\hline
\end{tabular}

In winter: after kidding until kids weaning (120 days). In summer: after weaning kids until end of lactating period (90 days).

These results are in agreement with those reported by Shah and Mir (2004) who found that adding fenugreek seeds to ration enhanced milk production in lactating cows. In addition, Wani and Kumar (2016) reported that fenugreek has been stimulated sweat glands production as it contains hormone precursor which could be working to increase milk formation. Moreover, lactating goats using $25 \%$ 
fenugreek showed higher significantly daily milk yield and milk fat percentage than the other two groups (zero or 50\%). Also, fenugreek has been recommended for the promotion of lactation. Fenugreek can increase a nursing mother's milk supply within 24-72 h after first taking the herb (Snehlata and Payal, 2012). Alamer and Basiouni (2005) found that fenugreek seeds increased milk production in dairy goats. Further evidences emphasized that fenugreek has a positive effect on lactation performance in dairy ruminants (El-Alamy et al., 2001 and Kholif and El-Gawad, 2001). Specifically, Diocin is a natural saponin found in fenugreek seeds and has a structural similarity to estrogen which leads to an increase releasing of growth hormone $(\mathrm{GH})$ by binding to the receptors on pituitary cells that recognize the $\mathrm{GH}$ releasing hormone. That, in turn, results in an increase in milk secretion (Graham et al., 2008). Fenugreek is well known around the world as a medicinal plant and for its medicinal properties in both humans and animals (Smith, 2003). Productivity of lactating animals can be improved by using medicinal plant seeds which increases growth hormone in the body and hormonal alert effects as circulating levels of prolactin and increase milk production (Khattab et al., 2010).

Milk compositions are illustrated in Table (6). Results obtained revealed that adding 30 gm GFS (G5) had significant increase milk fat percentage than those the other groups except G4. These results are in agreement with those reported by Wani and Kumar (2016) who found that lactating dairy goats using $25 \%$ fenugreek-ration showed higher significantly daily milk yield and milk fat percentage than those of zero-one. In contrary, results here appeared in disagreement with those obtained by Abo El-Nor et al. (2007) and Alamer and Basiouni (2005) who found that there was an insignificant effect on milk fat due to medicinal plant seeds supplementation into rations of lactating buffaloes and goats. However, Balgees et al. (2013b) reported that in Nubian goats, the milk fat content was reduced in groups given 10 and $15 \%$ FS compared with groups given 0 and 5\% FS. Regarding milk protein content in the present study, animals of G4 and G5 were higher significantly $(\mathrm{P}<0.05)$ in milk protein than that of $\mathrm{G} 1$ while, G2 and G3 were have an intermediate values. Otherwise, no significant differences among experimental treatments in lactose and SNF\%. These results are in agreement with those obtained by Degirmencioglu et al. (2016) who reported that using 5\% ground fenugreek seeds treatment had no significant effect on the percentages of SNF, protein or somatic cell count (SCC) in milk.

\section{Feed efficiency:}

Data of feed efficiency and changes in body weight are presented in Table (7). Results revealed that feed efficiency as $\mathrm{kg}$ milk/kg DMI, TDNI or DCPI either in winter or summer were somewhat increased

Table (7): Feed efficiency, live body weight and change in body weight of lactating Zaraibi goats during experimental period.

\begin{tabular}{lccccc}
\hline \multirow{2}{*}{ Items } & \multicolumn{5}{c}{ Experimental rations } \\
\cline { 2 - 6 } In winter & $\mathrm{G} 1$ & $\mathrm{G} 2$ & $\mathrm{G} 3$ & $\mathrm{G} 4$ & $\mathrm{G} 5$ \\
\hline Feed efficiency kg milk/kg DMI & & & & & \\
Feed efficiency kg milk/kg TDNI & 0.72 & 0.76 & 0.78 & 0.81 & 0.87 \\
Feed efficiency kg milk/kg DCPI & 0.99 & 1.03 & 1.03 & 1.06 & 1.11 \\
In summer & 6.28 & 6.55 & 6.66 & 6.86 & 7.17 \\
Feed efficiency kg milk/kg DMI & & & & & \\
Feed efficiency kg milk/kg TDNI & 0.56 & 0.60 & 0.61 & 0.67 & 0.70 \\
Feed efficiency kg milk/kg DCPI & 0.77 & 0.82 & 0.82 & 0.88 & 0.89 \\
Body weight of lactating goats, kg: & 5.50 & 5.85 & 5.91 & 6.39 & 6.45 \\
In winter (120 days ): & & & & & \\
$\quad$ Body weight after kidding & & & & & 34.7 \\
Body weight after 120 days & 28.0 & 32.9 & 30.9 & 34.3 & 34.0 \\
$\quad$ Change in body weight & 27.7 & 32.7 & 31.0 & 34.3 & 35.0 \\
In summer (90 days): & -0.3 & -0.2 & 0.1 & 0.0 & 0.3 \\
$\quad$ Body weight at 120 days & & & & & 35.0 \\
Final body weight & 27.7 & 32.7 & 31.0 & 34.3 & 35.0 \\
Change in body weight & 32.3 & 35.1 & 33.3 & 36.8 & 37.5 \\
& 4.6 & 2.4 & 2.3 & 2.5 & 2.5
\end{tabular}

In winter: after kidding until kids weaning (120 days). In summer: after weaning kids until end of lactating period (90 days). 
with increasing the level of additives and also with adding GFS comparing with DFS at the same level with superior over all to G5. These results had correlation effect with data of milk yield, feed intake and feeding values of group 5 (G5). These results are in agreement with results of Allam et al. (1999) who reported that milk production efficiency was increased for rations supplemented with dry fenugreek seeds by approximate 16\% compared to control. Moreover, Abdelhamid et al. (2011) found that improvement in feed conversion as DMI and CPI/milk yield reached to about 9.5 and 10\%; respectively compared to control. The positive effect of feed conversion efficiency was observed also by Abdelhamid et al. (2004) and Morteza et al. (2010) with using some medicinal herbs in small ruminant rations.

There were marked changes in goat's body weight during the experimental periods (winter and summer). From kidding up to weaning (winter period), body weight changes of goats was in favour of dietary treatments G3, G4 and G5, where goats did not lost any weight, corresponding to those on G1 and G2 whose lost 0.3 and $0.2 \mathrm{~kg}$, respectively, during this period. It means that GFS supplement into the ration of goats in their early lactation phase could be alleviating the effect of negative energy balance that almost appeared in this critical period. Also, these results may be due to high feed intake for goats of G5 than that of other treatments where it being attributed to fenugreek seed that stimulate the eating appetite which in turn causing on increasing of milk production. Furthermore, the improvement of production could be due to increasing the energy status and adequate time to recover body condition (Bocquier et al., 1993). While, in summer period, all animals' groups had markedly gained weight, but animals of all tested rations gained lesser weight than that of control group (G1). It might be attributed to lower of its milk production. On other hand, lactating goats fed supplemented rations with DFS or GFS were almost similar in their final weights with no lose of their weights because of the natural decrease in milk production curve from early lactation (winter) to late lactation periods (summer).

\section{Blood parameters:}

Table (8) illustrated the data of some blood parameters. There were no significant differences among dietary treatment respecting concentrations of blood globulin, urea, creatinine, ALT and AST before kidding, after four months of kidding and last lactating month. This means no deleterious effects on general health of the treated animals were observed due to adding fenugreek seeds either dry or germinated to rations of lactating Zaraibi goats.

While, total protein concentration after 4 month of kidding, was significantly higher with G5 than that of control group, but animals fed rations G1, G2, G3 and G4 had no significant differences among them. At last month of lactation period, concentration of total protein was significant with G3, G4 and G5 than control (G1) and insignificant higher than G2. Overall mean, the blood total protein concentration showed insignificant differences among experimental groups. Blood albumin concentration did not affect significantly due to dietary treatments in respect of before and after kidding by four months, while at last lactating month sample, albumin concentration was significant higher with G4 and G5 than that of G1 and G2 treatments and in addition the value of G3 did not differ significantly than the others ones. These results may be attributed to increase CP digestibility and DCP values for goats fed rations of G5 and G4 that illustrated in Table (5) at summer period.

These results are confirmed by experiment of Abo-El-Nor (1999) that found non-significant higher values of plasma total protein, albumin and non-significant lower values of urea, GOT, GPT for fenugreek seeds groups. Also, Allam et al. (1999) reported that values of serum TP and albumin were not affected, whereas, globulin was insignificantly higher $(\mathrm{P}<0.05)$ with adding fenugreek seeds than those of the control in pregnant Zaraibi does. While, Rashwan (1998) found that serum total protein was decreased with fenugreek supplementation and serum creatinine was not affected by fenugreek treatment using New-Zealand doe rabbits. Tomar et al. (1996) also reported that serum total protein was higher $(\mathrm{p}<0.05)$ by adding fenugreek seeds. In general, there weren't any worst effect on lactating goats health when fed on germinated or ungerminated fenugreek seeds as feed additives on a long run in their rations.

\section{Economic efficiency:}

Data in Table (9) showed feed intake (as fed) and economic efficiency. Results obtained revealed that goats fed ration supplemented with 30 gm GFS (G5) recorded the highest feed cost than those fed other rations. 
Table (8): Some blood parameters of lactating Zaraibi goats fed experimental rations (during experimental period).

\begin{tabular}{|c|c|c|c|c|c|c|c|}
\hline \multirow[b]{2}{*}{ Item } & \multirow[b]{2}{*}{ Time } & \multicolumn{5}{|c|}{ Experimental rations } & \multirow{2}{*}{$\pm \mathrm{SE}$} \\
\hline & & G1 & $\mathrm{G} 2$ & G3 & G4 & G5 & \\
\hline \multirow[t]{4}{*}{ T. protein $(\mathrm{g} / \mathrm{dl})$} & Before kidding & 7.02 & 7.06 & 7.03 & 6.93 & 6.89 & 0.58 \\
\hline & After kidding (4 month) & $6.90^{\mathrm{b}}$ & $7.04^{\mathrm{ab}}$ & $7.03^{\mathrm{ab}}$ & $7.07^{\mathrm{ab}}$ & $7.12^{\mathrm{a}}$ & 0.06 \\
\hline & After kidding (last lactating month) & $6.63^{\mathrm{b}}$ & $6.79^{\mathrm{ab}}$ & $7.00^{\mathrm{a}}$ & $6.95^{\mathrm{a}}$ & $7.06^{\mathrm{a}}$ & 0.09 \\
\hline & Overall mean & 6.85 & 6.96 & 7.02 & 6.98 & 7.02 & 0.23 \\
\hline \multirow[t]{4}{*}{ Albumin $(\mathrm{g} / \mathrm{dl})$} & Before kidding & 3.88 & 3.92 & 4.36 & 3.66 & 4.28 & 0.36 \\
\hline & After kidding (4 months) & 4.53 & 3.32 & 4.39 & 4.55 & 3.97 & 0.29 \\
\hline & After kidding (last lactating month) & $3.89^{\mathrm{b}}$ & $3.97^{\mathrm{b}}$ & $4.03^{\mathrm{ab}}$ & $4.16^{\mathrm{a}}$ & $4.15^{\mathrm{a}}$ & 0.05 \\
\hline & Overall mean & 4.10 & 3.74 & 4.26 & 4.12 & 4.13 & 0.20 \\
\hline \multirow[t]{4}{*}{ Globulin (g/dl) } & Before kidding & 3.14 & 3.13 & 2.87 & 3.27 & 2.60 & 0.45 \\
\hline & After kidding ( 4 months) & 2.37 & 3.72 & 2.64 & 2.52 & 3.14 & 0.52 \\
\hline & After kidding (last lactating m & 2.74 & 2.81 & 2.97 & 2.79 & 2.90 & 0.11 \\
\hline & Overall mean & 2.75 & 3.22 & 2.83 & 2.86 & 2.88 & 0.30 \\
\hline \multirow[t]{4}{*}{ Urea (mg/dl) } & Before kidding & 42.33 & 37.33 & 46.00 & 43.00 & 39.33 & 5.34 \\
\hline & After kidding (4 months) & 43.00 & 46.33 & 46.00 & 50.67 & 51.00 & 5.04 \\
\hline & After kidding (last lactating month) & 45.00 & 49.00 & 52.67 & 49.33 & 52.33 & 5.62 \\
\hline & Overall mean & 43.44 & 44.22 & 48.22 & 47.67 & 47.55 & 5.42 \\
\hline \multirow[t]{4}{*}{ Creatinine $(\mathrm{mg} / \mathrm{dl})$} & Before kidding & 1.39 & 1.25 & 1.10 & 1.26 & 1.31 & 0.11 \\
\hline & After kidding (4 months) & 1.33 & 1.31 & 1.30 & 1.29 & 1.30 & 0.13 \\
\hline & After kidding (last lactating month) & 1.41 & 1.32 & 1.34 & 1.30 & 1.21 & 0.08 \\
\hline & Overall mean & 1.38 & 1.29 & 1.25 & 1.28 & 1.27 & 0.12 \\
\hline \multirow[t]{4}{*}{ ALT (IU/L) } & Before kidding & 23.00 & 22.67 & 23.00 & 21.33 & 21.67 & 2.49 \\
\hline & After kidding (4 months) & 19.67 & 18.67 & 17.33 & 21.67 & 19.33 & 1.69 \\
\hline & After kidding (last lactating month) & 21.00 & 24.33 & 24.33 & 23.00 & 23.00 & 1.31 \\
\hline & Overall mean & 21.22 & 21.89 & 21.55 & 22.00 & 21.33 & 1.97 \\
\hline \multirow[t]{4}{*}{ AST (IU/L) } & Before kidding & 43.67 & 36.00 & 32.67 & 43.00 & 43.33 & 7.29 \\
\hline & After kidding (4 months) & 45.67 & 46.67 & 43.33 & 51.00 & 38.33 & 8.20 \\
\hline & After kidding (last lactating month) & 41.33 & 51.00 & 46.67 & 51.67 & 35.33 & 6.49 \\
\hline & Overall mean & 43.56 & 44.56 & 40.89 & 48.56 & 39.00 & 8.11 \\
\hline
\end{tabular}

$a$ and $b$ : Means in the same row with different superscripts are significantly different at $(P<0.05)$.

Table (9): Feed intake (as fed) and economical evaluation of lactating Zaraibi goats fed experimental rations (during total period, 210 days).

\begin{tabular}{|c|c|c|c|c|c|}
\hline \multirow{2}{*}{ Item } & \multicolumn{5}{|c|}{ Experimental rations } \\
\hline & G1 & $\mathrm{G} 2$ & G3 & G4 & G5 \\
\hline \multicolumn{6}{|l|}{ Feed intake (kg/goat/day) as fed: } \\
\hline Concentrate feed mixture (CFM) & 0.800 & 0.800 & 0.800 & 0.800 & 0.800 \\
\hline Berseem (in winter) & 4.05 & 4.10 & 4.16 & 4.22 & 4.33 \\
\hline Corn silage (in summer) & 1.46 & 1.48 & 1.51 & 1.53 & 1.56 \\
\hline Milk yield (kg/goat/day) & 0.795 & 0.855 & 0.880 & 0.941 & 1.004 \\
\hline \multicolumn{6}{|l|}{ Economical evaluation: } \\
\hline Price of additive (LE) & 0.00 & 0.09 & 0.09 & 0.27 & 0.27 \\
\hline Feed cost in winter without additive (LE/goat/day) & 2.65 & 2.66 & 2.68 & 2.69 & 2.71 \\
\hline Feed cost in summer without additive (LE/goat/day) & 2.19 & 2.19 & 2.20 & 2.21 & 2.21 \\
\hline Average total feed cost (210 days ; LE/goat/day) & 2.42 & 2.52 & 2.53 & 2.72 & 2.73 \\
\hline Price of milk production (LE/goat/day) & 3.58 & 3.85 & 3.96 & 4.23 & 4.52 \\
\hline Feed cost / kg milk & 3.04 & 2.94 & 2.88 & 2.89 & 2.72 \\
\hline Net revenue (LE/goat/day) ${ }^{\mathrm{A}}$ & 1.16 & 1.42 & 1.52 & 1.78 & 2.06 \\
\hline Economical efficiency ${ }^{\mathrm{B}}$ & 1.48 & 1.53 & 1.56 & 1.56 & 1.65 \\
\hline Improvement (\%) & 100 & 103 & 106 & 105 & 112 \\
\hline
\end{tabular}


It could be observed that feed cost in winter was increased by increasing feed intake and feed additive levels. There was the same trend in summer period, for feed cost as well as increasing average the total feed cost during 210 days. On the other hand, price of daily milk yield was the highest for G5 and the lowest value was recorded with animals of G1 (control). Net revenue (LE/goat/day) was the highest value for lactating goats received $30 \mathrm{gm}$ germinated fenugreek seeds (2.06 LE/goat/day) followed by G4, G3 and G2 which were recorded 1.78, 1.52 and 1.42, respectively, then (1.16) for G1. Economic efficiency values were 1.65 with improvement by $112 \%$ for G5, 1.56 with improvement by $105 \%$ for G4, 1.56 with improvement by $106 \%$ for G3 and 1.53 with improvement by $103 \%$ for G2 comparing with 1.48 as $100 \%$ for G1 (control). These results are confirmed by Mirzaei (2012) who reported that utilization of medicinal herbs support the farmer's income through produce more milk per animal. In addition, Abd El-Mola (2007) found that the diets containing medicinal plants could be economically and successfully be used for lactating animals to improve economical efficiency.

\section{Kids performance:}

Data in Table (10) showed growth performance (during the experimental suckling period) for kids that born from dams fed the experimental rations. Results revealed that kids in G5 group had significantly $(\mathrm{P}<0.05)$ the highest weaning weight among all experimental dietary treatments which reflect on gain weight (kg) and average daily gain (gm) where it had the same trend with superiority for kids in G5. Kids suckled from dams that fed 30 gm GFS (G5) also, had a significantly $(\mathrm{P}<0.05)$ the highest average daily gain $(89.9 \mathrm{gm})$ than those fed $30 \mathrm{gm}$ DFS (G4;82.7gm) followed by those fed $10 \mathrm{gm}$ GFS (G3; $73.6 \mathrm{gm})$ then those fed $10 \mathrm{gm}$ DFS (G2; $67.9 \mathrm{gm})$ and lastly those of their dams fed control ration $(63.3 \mathrm{gm})$. These results are in agreement with the findings obtained by Weinberg et al. (2003) and Yahaya et al. (2004) who stated that increasing milk yield of dams will lead to increase weaning weight of the offspring. In this study, it observed that there were differences in mortality rates between experimental groups. Kids of dams fed 30 gm GFS (G5) and 30 gm DFS (G4) had zero mortality percent comparing with $28.6,14.3$ and $6.25 \%$ for $\mathrm{G} 1, \mathrm{G} 2$ and $\mathrm{G} 3$; respectively.

Table (10): Growth performance and mortality rate of kids during suckling period (120 days; winter).

\begin{tabular}{lcccccc}
\hline \multirow{2}{*}{ Item } & \multicolumn{6}{c}{ Experimental rations } \\
\cline { 2 - 6 } & $\mathrm{G} 1$ & $\mathrm{G} 2$ & $\mathrm{G} 3$ & $\mathrm{G} 4$ & $\mathrm{G} 5$ & \\
\hline No. born kids & 14 & 14 & 16 & 15 & 14 & \\
Birth weight $(\mathrm{kg})$ & $2.5^{\mathrm{c}}$ & $2.7^{\mathrm{c}}$ & $2.7^{\mathrm{c}}$ & $2.9^{\mathrm{b}}$ & $3.1^{\mathrm{a}}$ & 0.06 \\
Weaning weight $(\mathrm{kg})$ & $10.1^{\mathrm{d}}$ & $10.8^{\mathrm{d}}$ & $11.5^{\mathrm{c}}$ & $12.8^{\mathrm{b}}$ & $13.9^{\mathrm{a}}$ & 0.25 \\
Total gain (kg) & $7.6^{\mathrm{d}}$ & $8.2^{\mathrm{d}}$ & $8.8^{\mathrm{c}}$ & $9.9^{\mathrm{b}}$ & $10.8^{\mathrm{a}}$ & 0.21 \\
ADG (gm) & $63.3^{\mathrm{d}}$ & $67.9^{\mathrm{d}}$ & $73.6^{\mathrm{c}}$ & $82.7^{\mathrm{b}}$ & $89.9^{\mathrm{a}}$ & 1.76 \\
No. of mortality kids & 4 & 2 & 1 & 0 & 0 & \\
Mortality kids (\%) & 28.6 & 14.3 & 6.25 & 0 & 0 & \\
\hline
\end{tabular}

$a, b, c$ and $d$ : Means in the same row with different superscripts are significantly different at $(P<0.05)$.

These results probably due to the mobilization of immune body reserves from dams fed on higher levels of DFS or GFS rations into their born kids and as well as the improvement in their kids metabolism. These results are confirmed by findings of Carol et al. (1996) and Thirunavukkarasu et al. (2003) who found that fenugreek seed in powder or germinated must have privilege to ameliorate the animal health represented in supporting a good immunity protective effect on animal production. Mortality is the matter of concern for producers because it is directly linked with economic loss as mentioned by Kumar et al. (2003) who reported that economic losses due to mortality in goats have been a major constraint in the traditional flocks.

\section{Reproductive performance of does in next mating season:}

Results presented in Table (11) illustrated estrus rate, fertility rate relative to mated does and to total does and prolificacy trait. Regarding of estrus rate was significant higher in G3 and G5 than that of G1 and G2 and insignificant higher than that of G4. Also, fertility rate relative to mated does recorded the highest $(\mathrm{p}<0.05)$ values for G4 and G5 than that of G1 and G2. In the same trend, fertility rate $(\%)$ relative to total does was highest significantly $(\mathrm{p}<0.05)$ in G5 than control group and G2 while, G3 and G4 were intermediate. The same trend was observed for prolificacy trait.

Generally, there was improvement in reproductive performance in fertility and prolificacy traits of does fed rations supplemented with 30 gm GFS followed by 30 gm DFS comparing with those of other 


\section{Abou-Elenin et al.}

ones. This may be attributed to normal physiological response due to increase an improvement of feed utilization (Table 5) as well as TDN, DCP and DE (energy intake) and these reflect on increasing the energy status and adequate time to recovery body condition and high body weight and its changes (Table 7) with adding $30 \mathrm{gm}$ fenugreek seeds (dry or germinated). These results are in consistent with those obtained by Thomes and Williams (1996) who indicated that fenugreek seeds (Trigonella foneumgraecum L.) might be stimulated pituitary gland to secrete gonadotrophines which suppress progesterone secretion. This is in agreement with observations mentioned by Blauwiekel and Kincaid (1986) and Shesworth and Esdon (1983) who found that dietary protein can alter the secretion of progesterone and LH in cattle. Bocquier et al. (1993) suggested that ewes that gained $1 \mathrm{~kg}$ of body weight during the first month after lambing had the shortest an ovulation period and the ovulation period was more closely related to body weight change.

Table (11): Reproductive performance of lactating Zaraibi goats fed experimental rations in next mating season.

\begin{tabular}{lcccccc}
\hline \multirow{2}{*}{ Items } & \multicolumn{5}{c}{ Experimental rations } & \multirow{2}{*}{ SE } \\
\cline { 2 - 6 } & $\mathrm{G} 1$ & $\mathrm{G} 2$ & $\mathrm{G} 3$ & $\mathrm{G} 4$ & $\mathrm{G} 5$ & --- \\
\hline No. of does (n) & 9 & 9 & 9 & 9 & 9 & --- \\
No. of does estrus, mated (n) & 7 & 7 & 9 & 8 & 9 & 8.4 \\
Estrus rate (\%) & $77.7^{\mathrm{b}}$ & $77.7^{\mathrm{b}}$ & $100.0^{\mathrm{a}}$ & $88.8^{\mathrm{ab}}$ & $100^{\mathrm{a}}$ & 4.4 \\
No. of does kidded (n) & 6 & 6 & 8 & 8 & 9 & --- \\
Fertility rate (\%) relative to mated does & $85.7^{\mathrm{b}}$ & $85.7^{\mathrm{b}}$ & $88.8^{\mathrm{ab}}$ & $100^{\mathrm{a}}$ & $100^{\mathrm{a}}$ & 3.9 \\
Fertility rate (\%) relative to total does & $66.6^{\mathrm{b}}$ & $66.6^{\mathrm{b}}$ & $88.8^{\mathrm{ab}}$ & $88.8^{\mathrm{ab}}$ & $100^{\mathrm{a}}$ & 4.3 \\
Total number of kids born & 8 & 8 & 11 & 12 & 16 & --- \\
Prolificacy (No. of kids born/ does kidding) & $1.33^{\mathrm{b}}$ & $1.33^{\mathrm{b}}$ & $1.37^{\mathrm{ab}}$ & $1.50^{\mathrm{ab}}$ & $1.77^{\mathrm{a}}$ & 0.12 \\
\hline a and b: Means in the same rows with different superscripts are significantly different at $(P<0.05)$. & \multicolumn{5}{c}{}
\end{tabular}

\section{CONCLUSION}

It could be concluded that using fenugreek seeds either dry or germinated as feed additives had more positive effects on productive performance of lactating Zaraibi goats. In addition to, increasing levels of fenugreek seeds up to $30 \mathrm{gm}$ are also enhancing productive performance of dairy goats. Moreover, using level of $30 \mathrm{gm}$ germinated fenugreek seeds as natural additives in rations of lactating Zaraibi goats tended to improve feed intake, digestibility, feeding values and milk production. Also, using germinated fenugreek seeds could increase the values of feed efficiency, economic efficiency, suckled kids performance, thus, decrease kids mortality rate and enhance reproductive performance for goats in next mating with no deleterious effects on general health of the experimental animals. So, using fenugreek seeds in germinated form is recommended for supplementation by level of $30 \mathrm{gm} / \mathrm{goat} / \mathrm{day}$, into the rations of lactating goats.

\section{REFERENCES}

Abd El-Mola, A. M. (2007). Medicinal plants as feed additives for ruminants. Thesis of Master in Agricultural Sciences (Animal Nutrition), Department of Animal production, Faculty of Agriculture, Fayoum University.

Abdelhamid, A. M.; E. I. Shehata and G. A. Maged (2011). Effect of some medical herbs on production of lactating Zaraibi goats. J. Animal and Poultry Prod., Mansoura Univ., 2 (12): 493 - 513.

Abdelhamid, A M.; M.E.Ahmed; E.1.Shehata; Faten F. Abou Ammou and G.A. Maged (2004). Impact of using chamomile flower on the performance of Rahmani sheep. J. Agric. Sci. Mansoura Univ., 29: 6105-6117.

Abo El-Nor, S.A.H. (1999). Influence of fenugreek seeds as a glactogogue on milk yield, milk composition and different blood biochemical of lactating buffaloes during mid-lactation, Egypt. J. Dairy Sci., 27: 231-238.

Abo El-Nor, S. A. H., H. M. Khattab, H. A. Al-Alamy, F. A. Salem and M. M. Abdou (2007) Effect of some medicinal plants seeds in the rations on the productive performance of lactating buffaloes, Int. J. Dairy Sci., 2, 348-355. 
Alamer, M.A. and G.F. Basiouni (2005). Feeding effects of fenugreek seeds (Trigonella foenum-graecum $L$ ) on lactation performance, some plasma constituents and growth hormone level in goats. Pak. J. Biol. Sci., 8:1553-1556.

Ali, M.F., M.S. Saleh, N.M. Eweedah and S.A. Mahmoud (2005). Effect of using chamomile (Mtricaria chamomilla) flowers as feed additives on performance of growing lambs under desert farming systems. Egypt. J. Nutr. Feeds, 8: 127-137

Allam, S. M.; Hoda M. El-Hosseiny; A. M. Abdel Gawad; S. A. El-Saadany and A. M. M. Zeid(1999). Medicinal herbs and plants as feed additives for ruminants. 1. Effect of using some medicinal herbs and plants as feed additives on Zaraibi goats performance. Egypt. J. Nutrition and feeds. 2 (special Issue: $349-365)$.

AOAC (1995). Official Methods of Analysis of AOAC International, 16th ed. Agricultural, Chemicals, Contaminates, Drugs, vol.1.Washington, D. C, USA.

AOAC (1997). Official Methods of Analysis AOAC Int., Gaithersburg, MD.

Armstrong, W. D. and C. W. Carr (1964). Physiological Chemistry 3rd ed. pp., 75 Burges Publishing CO. Minneapolis, Minnesota, USA.

Balgees, A., A. Elmnan, F. A.Rewais, A.M.A F. Elseed, A.G. Mahala and E.O. Amasiab (2013a). Effect of supplementation of fenugreek (Trigonellafoenum graecum L.) seeds on feed intake, digestibility, $\mathrm{N}$-balance and rumen environment of Nubian goats. International Journal of Development and Sustainability, 2:(2), 1214-1223.

Balgees, A., A. Elmnan, M. Jame, S. A. Rahmatalla, E. O., Amasiab and A.G. Mahala (2013b). Effect of fenugreek (Ttrigonella foenum graecum) seeds supplementation on feed intake, some metabolic hormones profile, milk yield and composition of Nubian goats, Res. J. Anim. Sci., 7, 1-5.

Blauwiekel, R. and R.L. Kincaid (1986). Effect of crude protein and solubility on performance and blood constituents of dairy cows. J. Dairy Sci., 69: 2091-2098.

Bocquier, F.; G.Kann, and J. Thimonler (1993). Effect of body composition variations on the duration of the postpartum anovulatory period in milked ewes submitted to different photoperiods. Reprod. Nutr. Develop. 33(4): 395.

Borca, C., M. Manteghetti and R. Corss (2000). 4-Hydroxyisoleucine: effect of synthetic and natured analogs on insulin secretion, European J. Pharmacol, 390, 3: 339-354.

Carol, A.N., A.A. Linda and J. P. David (1996). Herbal medicines. A Guide for Health-Care Professionals. 117-118.

Chen, L. H., C. E. Wells and J. R. Fordham (1975). Germination of seeds for human consumption. J. Food Sci., 40, 1290.

Chen, P. S. (1970). Soybean for health, longevity and economy. $3^{\text {rd }}$ Ed. Provoker Press St., Catherine Ant., Canada.

Degirmencioglu, T.; H. Unal, S. Ozbilgin and H. Kuraloglu (2016). Effect of ground fenugreek seeds (Trigonellafoenum graecum) on feed consumption and milk performance in Anatolian water buffaloes. Arch. Anim. Breed., 59, 345-349.

Doumas, B.; W. Waston and H. Biggs (1971). Albumin standards and measurements of serum with bromocresol green. Clin. Chem. Acta, 31: 87.

Duncan, D.B. (1955). The multiple range and F test. Biometrics, 11: 1-45.

El-Alamy, H., H. Khattab, S. El-Nor, F. Salam and M. Abdou (2001). Milk production response to supplementing rations with some medicinal herbs of lactating buffaloes. 8th Egyptian Conference for Dairy Science and Technology, Research Papers II, 678-686.

E1-Mahdy, A. R. and L. A. E1-Sebaiy (1982). Effect of germination on the nitrogenous constituents, protein fractions, in-vitro digestibility and anti-nutritional factors of fenugreek seeds (Trigonellafoenum graecum L.). Food Chem., 8, 253-62.

E1-Shimi, N. M., A. A. Damir and M. Ragab (1984). Changes in Some Nutrients of Fenugreek Seeds During Germination. Food Chemistry, 14: 11-19.

Fawcett, J. K and J. E., Scott (1960). J, Clin., Path. 13:156-159. 


\section{Abou-Elenin et al.}

Frankič, T., M., Voljč, J.Salobir, and V., Rezar (2009). Use of herbs and spices and their extracts in animal nutrition. Acta Agricultural Eslovenica, 94: 95-102.

Gad, S. S., M. E. El-Zalaki, M. S. Mohamed and Zeinab S. Mohasseb (1982a).Oxalate content of some leafy vegetables and dry legumes consumed widely in Egypt. Food Chemistry 8:169-177.

Gad, S. S., M. S. Mohamed, M. E. El-Zalaki, and Zeinab S. Mohasseb (1982b). Effect of processing on phosphorus and phytic acid content of some Egyptian varieties of legumes. Food Chem., 8, 11- 19.

Gaines, W.L. (1928). The Energy Basis of Measuring Energy Milk in Dairy Cows. Univ. Illinois Agric.

Graham, M.R., J.S., Baker, P., Evans, A., Kicman, D., Cowan, D., Hullin, N. Thomas, and B., Davies (2008). Physical effects of short-term recombinant human growth hormone administration in abstinent steroid dependency. Horm. Res. Paediatr., 69: 343-354.

Ismail, S.A. (2000). Effect of fenugreek seeds (Trigonellafoenum graecumL.) as feed additive on sheep performance in the Northwestern coast of Egypt. Proc.3rd All Africa Conf. Anim. Agric.11th Conf. Egyptian Soc. Anim. Prod. Alex., Egypt. 6-9 November, pp. 321-325.

Kamel, C. (2000). A novel look at a classic approach of plant extracts, Feed Mix, 8, 16-18.

Kamer, A. Ayate, Abo-Bakr, M. Taiseer, El-Zalaki M. Esmat, and M. B. Zoueil (1982). Evaluation of the proteins of deflavoured fenugreek powder. Alex. J. Agric. Res. 30: 197-206.

Kamer, A. Ayate, El-Zalaki, M. Esmat, Abo-Bakr, M. Taiseer and M. B. Zoueil (1980). Deflavouring of fenugreek powder as a cereal supplement. Alex. J. Agric. Res. 28: 531-535.

Khattab, H., S., Abo El-Nor, S., Kholif, H., El-Sayed, O. Abd El-Shaffy and M. Saada (2010). Effect of different additive sources on milk yield and composition of lactating buffaloes. Livest. Sci., 131:8-14.

Kholif, A. and M.A., El-Gawad (2001). Medicinal plant seeds supplementation of lactating goats diets and its effects on milk and cheese quantity and quality. Egypt. J. Dairy Sci., 29: 139-150.

Kumar, S., V.S. Vihan and P.R. Deoghare (2003). Economic implications of diseases in goats in India with reference to implementation of a health plane calendar. Small Rumi. Res., 47:159-164.

Mirzaei, F. (2012). Effect of Herbal Feed Additives on Performance Parameters of Ruminants and Especially on Dairy Goat: A Review. International Journal for Agro Veterinary and Medical Sciences, 6, Issue 5, 2012: 307-331.

Morteza, K.; A. Abd-Razak, Y. Goh, Q. S. Awis and M. Ivan (2010). Effects of dietary herbal antioxidants supplemented on feedlot growth performance and carcass composition of male goats. Amer. J. of Ani. and Vet. Sci., 5 (1): 33.

NRC (1981). National Research Council. Nutrient Requirements for goats. Nat. Acad. Sci., Washington, DC.

NRC (1988). Nutrient Requirements of Dairy Cattle. $6^{\text {th }}$ Rev. Ed., National Research Council, Acad. Sci., Washington, DC, USA.

Petit, P., Y. Sauvaire, G. Ponsin, M. Manteghetti, A. Fave and G. Ribes (1993). Effects of a fenugreek seed extract on feeding behavior in the rat: Metabolic endocrine correlates, Pharmacol. Biochem. Behav., 45, 369-374.

Rahman, M. M., T. Nakagawa, M. Niimi, K. Fukuyama and O. Kawamura (2011). Effect of feeding oxalate containing grass on intake and the concentrations of some minerals and parathyroid hormone in blood of sheep. Asian-Aust. J. Anim. Sci. Vol. 24, No. 7:940-945.

Rashwan, A. A. (1998). Effect of dietary addition of anise, fenugreek and caraway on reproductive and performance of New Zealand white rabbit does. Egyptian J. of Rabbit Sci., 8: 2, 157-167.

SAS (2000). Statistical Analysis Systems. Version 9.2, SAS Institute, Cary, NC.

Schirmeister., J. (1964). Dtsch. Med Waschr. 89.

Shah, M. A. and P. S. Mir (2004). Effect of dietary fenugreek seed on dairy cow performance and milk characteristics. Can. J. Anim. Sci. 84: 725-729.

Shesworth, J.M. and M.P. Esdon (1983). Effect of diet and season on steroid hormones in the ruminant. J. Steroid Biochem., 19:715. 
Silva, H. and B. S. Luh, (1979). Scanning detection microscopy studies on starch granules of red kidney beans and bean sprouts. J. Food Sci., 43, 1405.

Smith, M., (2003). Therapeutic applications of Fenugreek. Alternative Medicine: A review., 8: 20-27.

Snehlata, H.S. and D.R. Payal (2012). Fenugreek (Trigonella foenum graecum L.): an overview. Int. J. Curr. Pharm. Rev. Res. 2 (4), 169-187.

Thirunavukkarasu, V., C. V. Anuradha and P. Viswanathan (2003). Protective effect of fenugreek (Trigonellafoenum graecum) seeds in experimental ethanol toxicity. Phytotherapy Research, 17:737743.

Thomes, M. G. and G. L. Williams (1996). Metabolic hormone secretion and FSH induced superovulatory responses of beef heifers fed dietary fat supplemented containing prodomintly saturated or polyunsaturated fatty acids. Theriogenology, 45: 451.

Tomar, K.S., V.P. Singh and R.S. Yadav (1996). Effect of feeding maithy (Trigonella foenum graecum) and chandrasoor (Lepidium sativum) seeds on milk and blood constituents of Murrah buffaloes. Indian J. Anim. Sci., 66 No. 11: 1192-1193.

Valdez, F.R., L.J., Bush, A.L. Goetsch and F.N. Owens (1986). Effect of steroidal sapogenins on ruminal fermentation and on production of lactating dairy cows, J. Dairy Sci., 69: 1568-1575.

Van Keulen, J. and B. A. Young (1977). Evaluation of acid insoluble ash as a nature marker in ruminant digestibility studies. J. Anim. Sci., 44:282- 287.

Wani, S.A. and P. Kumar (2016). Fenugreek: A review on its nutraceutical properties and utilization in various food products. J. of the Saudi Society of Agricultural Sciences. (In press). Cited by (http://creativecommons.org/licenses/by-nc-nd/4.0/).

Weinberg, Z.G.,R.E. Muck and P.J. Weimer (2003). The survival of silage inoculants lactic acid bacteria in rumen fluid. J.App.Microb.94: 1066 -1071.

Yahaya, M.S., M. Goto, W. Yimit, B. Smerjai and Y. Kawamoto (2004). Evaluation of fermentation quality of a tropical and temperate forage crops ensiled with additives of fermented juice of Epiphytic lactic acid bacteria (FJLB). Asian-Aust. J. Anim. Sci., 17: 942 -946.

Young, D. S. (1990). Effects of drugs on clinical laboratory tests. $3^{\text {rd }}$ Ed. 3:6-12. 
تأثير استخدام مستويات مختلفة من بذور الحلبة الجافة والمستتبتة على الأداء الإنتاجي والتتاسلـي في المـاعز

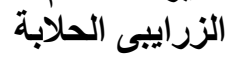

إبتهاج إبراهيم محما أبو العنين، محمد محمود البدوى، هبة عبد الرحيم الصنفاوى ، يوسف حسين حافظ

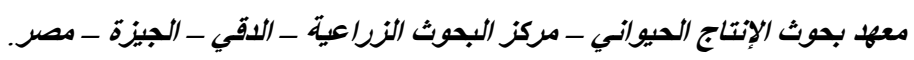

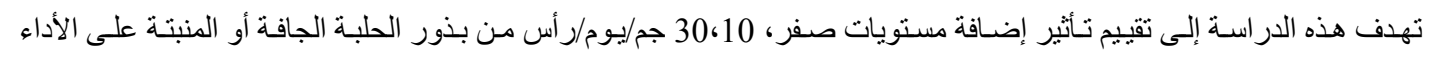

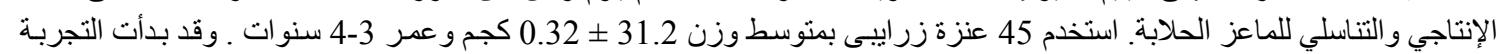

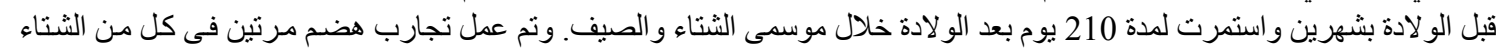

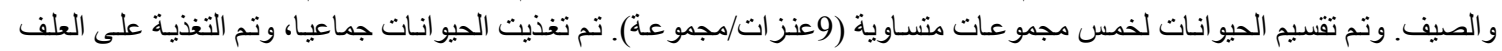
المركز بنسبة 50\% من مقررات NRC (1981) بينما كان العلف المالئ حتى الثبع وكانت المعاملات كالتالي في كل من الصيف و الثناء:

$$
\begin{aligned}
& \text { المجمو عة الأولى (كتترول) (في الثتاء): علف مركز + برسيم حتى الثبع. }
\end{aligned}
$$

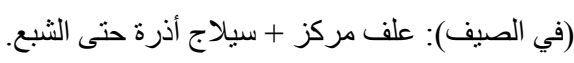

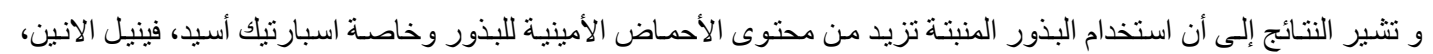

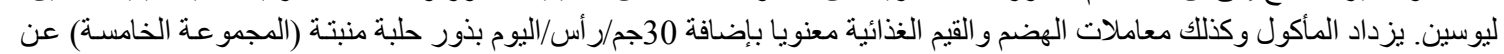

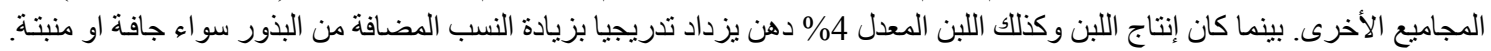

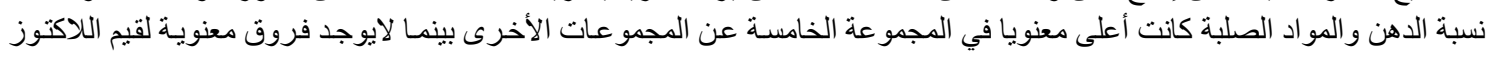

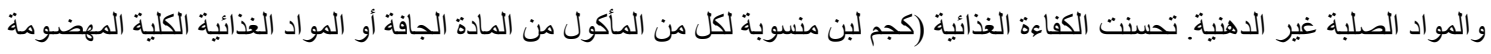

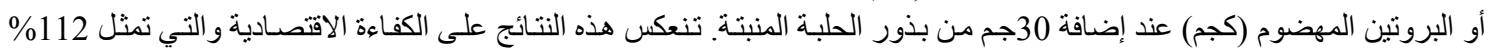

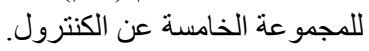

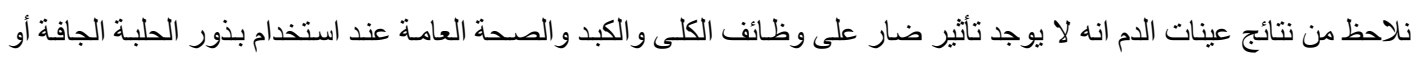

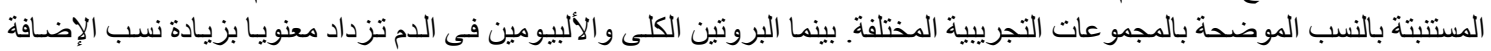

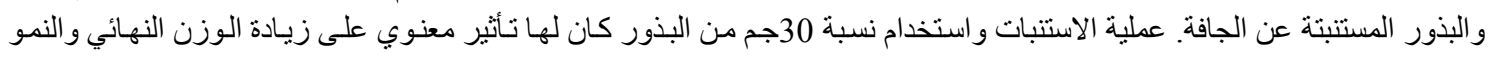

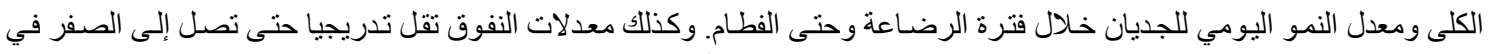

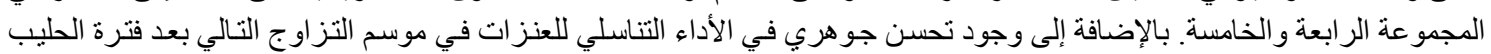
محل الدراسة.

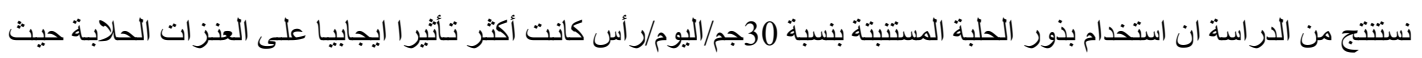

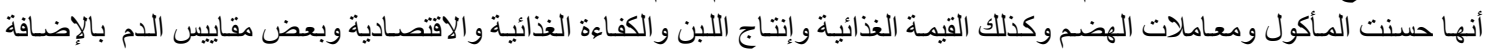

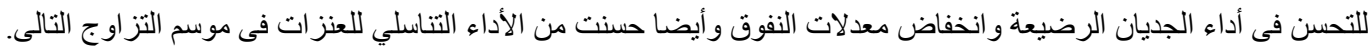

